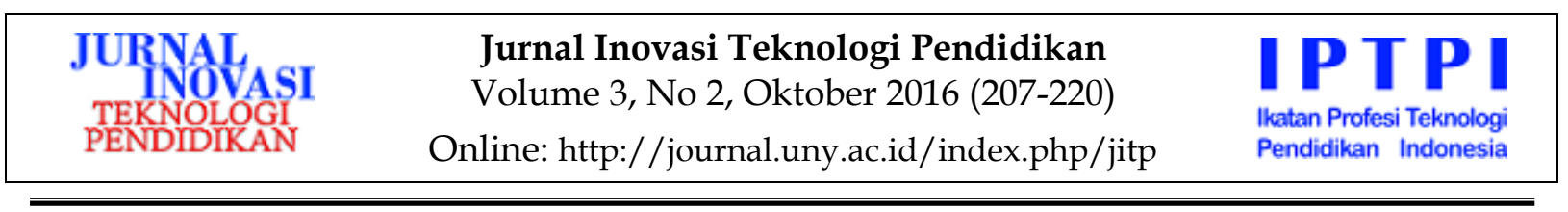

\title{
PENGEMBANGAN MULTIMEDIA PEMBELAJARAN KARTOGRAFI PADA JURUSAN PENDIDIKAN GEOGRAFI FAKULTAS ILMU SOSIAL UNY
}

\author{
1)Kimpul Endro Sariyono, 2)Mukminan \\ 1, 2)Jurusan Pendidikan Geografi Fakultas Ilmu Sosial Universitas Negeri Yogyakarta \\ kimpul.endro@gmail.com dan mukminan@yahoo.com
}

\begin{abstract}
Abstrak
Penelitian ini bertujuan: (1) menghasilkan multimedia pembelajaran kartografi dan (2) mengetahui kelayakan multimedia pembelajaran dari aspek materi, aspek tampilan dan kelayakan untuk pembelajaran. Penelitian ini merupakan penelitian dan pengembangan (research and development). Produk awal divalidasi oleh ahli materi dan ahli media kemudian diujicobakan. Subjek uji coba produk adalah mahasiswa Jurusan Pendidikan Geografi Fakultas Ilmu Sosial UNY. Data yang dikumpulkan dalam penelitian ini adalah data dari ahli materi, data ahli media, dan tanggapan mahasiswa terhadap daya tarik media. Instrumen pengumpulan data berupa lembar evaluasi untuk ahli materi dan ahli media, serta lembar angket untuk uji coba kelompok kecil dan uji coba lapangan. Analisis data menggunakan analisis deskriptif. Hasil penelitian ini adalah: (1) hasil pengembangan multimedia pembelajaran melalui tahap persiapan, desain, produksi, uji coba, dan revisi; 2) kualitas media ditinjau dari aspek materi termasuk kategori sangat baik; (3) kualitas media ditinjau dari aspek tampilan termasuk kategori baik; (4) tanggapan mahasiswa tentang daya tarik media termasuk kriteria sangat menarik; dan (5) evaluasi hasil belajar menunjukkan lebih dari $75 \%$ mahasiswa mampu menguasai kompetensi pembelajaran menggunakan multimedia yang dikembangkan.
\end{abstract}

Kata kunci: kartografi, multimedia

\section{DEVELOPING COMPUTER-BASED INSTRUCTION MULTIMEDIA FOR CARTOGRAPHY AT GEOGRAPHY EDUCATION YOGYAKARTA STATE UNIVERSITY}

\author{
1)Kimpul Endro Sariyono, 2)Mukminan \\ 1, 2)Jurusan Pendidikan Geografi Fakultas Ilmu Sosial Universitas Negeri Yogyakarta \\ kimpul.endro@gmail.com dan mukminan@yahoo.com
}

\begin{abstract}
This research aims: (1)to product multimedia for cartography; and (2)to reveal the quality of the developed instructional media viewed from the aspects of content, appearance, and attraction for instruction. This research is research and development. The initial product was validated by an expert in subject matter and an expert in media and then was trying out. The subject of product trials are students from the Department of Geography Education Faculty of Social Sciences Yogyakarta State University. The data were collected using an evaluation sheet for the subject matter expert, the media expert, and questionnaire sheet for the one-to-one try-out, the small group try-out, and the field tryout. The data were analyzed using the statistic descriptive technique. The research results show that: (1)the steps in developing computer-based multi media was in some stages, namely, need analysis, design, production, try-out, and revision; (2) the quality of the developed instructional media viewed from the content aspects is very good; (3) the quality of the developed instructional media in terms of the appearance aspects is good; (4) the quality of the developed instructional media in regard to the attraction aspects is interesting; and 5) result of study explain more than $75 \%$ of students competen to received the targets of study with this multimedia.
\end{abstract}

Keywords: cartography, multimedia 


\section{Pendahuluan}

Pembelajaran merupakan proses yang kompleks yang berlangsung di kelas. Dosen mengajar tidak sekedar menyampaian pesan kepada mahasiswa, tetapi penyampaian harus dilandasi dengan berbagai wawasan dan menggunakan berbagai keterampilan. Pembelajaran merupakan terjemahan dari kata "Instruction", yaitu merupakan serangkaian kegiatan yang dirancang untuk memungkinkan terjadinya proses belajar pada mahasiswa. Instruction is a set of events that effect learners in such a way that learning is facilitatated (Gagne, Briggs, \& Wager, 1992, p.3).

Dalam proses pembelajaran ada dua unsur yang sangat penting yaitu metode dan media pembelajaran. Media dari kata "medium" berarti perantara, pengantar pesan dari pengirim ke penerima pesan. Salah satu tujuan penggunaan media pembelajaran adalah sebagai alat bantu yang turut mempengaruhi iklim, kondisi, lingkungan belajar yang ditata dan diciptakan oleh dosen. Penggunaan media pembelajaran dimaksudkan agar ada rangsangan dan motivasi mahasiswa dalam kegiatan belajar. Di samping itu bahan pembelajaran akan lebih jelas maknanya sehingga dapat lebih dipahami oleh mahasiswa/ mahasiswa(Arsyad, 2005, pp.15-16).

Demikian pula halnya, pada pembelajaran kartografi pada Jurusan Pendidikan Geografi dengan alat dan media untuk keperluan teori dan praktek, dosen sangat mengandalkan metode ceramah dan menampilkan media yang sudah disiapkan diselingi tanya jawab. Pada materi-materi tertentu diberikan formula-formula/rumusrumus tertentu untuk mengerjakan latihan soal yang harus diselesaikan pada saat perkuliahan. Dalam menyelesaikan latihan soal tersebut, diperlukan tanya jawab dan diskusi tentang langkah-langkah yang harus dilakukan. Dalam hal ini metode pembelajaran diharapkan menjadi lebih menarik bila menggunakan media pembelajaran berbantuan komputer (multimedia). Sehingga mahasiswa lebih kreatif dan mandiri.
Komputer sekarang ini sudah merupakan barang yang mudah diperoleh, hampir setiap sekolah sudah memanfaatkannya, bahkan sudah banyak mahasiswa yang memiliki komputer pribadi. Oleh karena itu dalam proses pembelajaran di perguruan tinggi khususnya pembelajaran kartografi sudah seharusnya menggunakan multimedia. Namun demikian dalam praktiknya masih menghadapi banyak kendala dalam pelaksanaan di lapangan. Hal ini karena masih ada dosen yang kesulitan dalam menggunakan multimedia yang berbantuan komputer, dan kurangnya dukungan pihak lembaga untuk pengadaan media pembelajaran khususnya komputer dan ruangan yang memadai untuk sejumlah besar mahasiswa.

Whitworth \& Berson (2003) mengemukakan bahwa "Technology-based learning has the potential to facilitate development of students' decision-making and problem solving skills, data processing skills, and communication capabilities. Through the computer, students may gain access to expansive knowledge links and broaden their exposure to diverse people and perspectives; hence, affording students the opportunity to become active participants in an increasingly global and interactive world. Dengan memperhatikan uraian tersebut, perlu adanya media pembelajaran untuk mata kuliah kartografi khususnya materi menghitung volume cekungan bagi mahasiswa Jurusan Pendidikan Geografi Fakultas Ilmu Pengetahuan Sosial Universitas Negeri Yogyakarta. Penelitian ini berusaha mengembangkan software berupa multi media berbasis komputer pembelajaran kartografi, dengan pokok bahasan "menghitung volume cekungan". Software ini setelah dibuat, dikaji oleh ahli media dan ahli materi kemudian diujicobakan kepada mahasiswa agar media pembelajaran tersebut dapat digunakan untuk pembelajaran materi kartografi, Jurusan Pendidikan Geografi Fakultas Ilmu Sosial Universitas Negeri Yogyakarta.

Berdasrkan uraian yang telah dipaparkan, penelitian ini bertujuan: (1) menghasilkan multimedia pembelajaran 
kartografi dan (2) mengetahui kelayakan multimedia pembelajaran dari aspek materi, aspek tampilan dan kelayakan untuk pembelajaran.

\section{Metode Penelitian}

Penelitian ini termasuk jenis penelitian dan pengembangan atau research and development $(R \mathcal{E} D)$. Penelitian ini bertujuan untuk mengembangkan multimedia pembelajaran mata kuliah kartografi bagi mahasiswa Jurusan Pendidikan Geografi Fakultas Ilmu Sosial Universitas Negeri Yogyakarta khususnya materi menghitung volume cekungan. Isi multimedia ini merupakan proses interpretasi peta. Pengertian interpretasi peta merupakan proses lanjut dari analisa peta yaitu dengan mengaitkan antara hasil analisa yang di peroleh dengan disiplin ilmu-ilmu lain yang berhubungan dengan segala data dan fenomena/gejala yang tercakup dalam suatu peta (Sandy, 1986, p.3).

Penelitian dan pengembangan di sini mencakup proses pengembangan dan validasi produk sebagaimana dikemukakan oleh Borg \& Gall (1983). Desain pembelajaran yang digunakan dalam mengembangkan media pembelajaran ini model Dick, Carey, \& Carey (2005). Sedangkan pengembangan media menggunakan model Luther. Desain evaluasi produk menggunakan evaluasi formatif yaitu uji coba lapangan.

Penelitian ini termasuk jenis penelitian dan pengembangan atau research and development (RED). Penelitian ini di laksanakan di Jurusan Pendidikan Geografi Fakultas Ilmu Sosial Universitas Negeri Yogyakarta, pada Semester Gasal 2011/2012. Subjek penelitian ini adalah mahasiswa Jurusan Pendidikan Geografi Fakultas Ilmu Sosial UNY yang mengikuti mata kuliah Kartografi, sehingga pada penelitian ini populasi dan sampelnya adalah sebagian dari peserta mata kuliah Kartografi tersebut dengan cara acak atau random.

Prosedur penelitian dan pengembangan ini merupakan gabungan dari beberapa prosedur yang dikemukakan oleh para ahli. Sedangkan dalam pengembangan multimedia pembelajaran, menggunakan beberapa tahap seperti yang dikemukakan oleh Elinor L. Criswell (Sadiman, Raharjo, \& Haryono, 2009, p.12).

Pengembangan tersebut terdiri: menentukan mata kuliah yang akan dikembangkan, mengidentifikasi silabus mata kuliah, pengembangan software pembelajaran yang terdiri dari tujuh langkah yaitu: (1) menentukan standar kompetensi; (2) menentukan kompetensi dasar; (3) melakukan analisis pembelajaran; (4) merumuskan indikator; (5) mengembangkan instrumen penilaian; (6) mengembangkan materi pembelajaran; dan (7) menyusun strategi pembelajaran.

Persiapan pembuatan media pembelajaran meliputi: menyiapkan materi yang dibutuhkan, seperti audio, movie, animasi, teks, dan gambar, membuat flowchart, membuat storyboard, membuat software pembelajaran, menyimpan software pembelajaran yang telah dibuat ke compact disk $(C D)$.

Ujicoba dan revisi produk yang terdiri: validasi ahli media dan ahli materi, revisi produk atas review ahli media dan ahli materi, uji coba produk meliputi: uji coba perorangan, uji coba kelompok kecil, dan uji coba lapangan, revisi akhir produk.

Dalam mengembangkan produk media pembelajaran berbasis komputer, produk yang dikembangkan melalui proses validasi oleh ahli materi, validasi oleh ahli media serta uji coba perorangan, uji coba kelompok kecil, dan uji coba lapangan. Validasi oleh ahli dan uji coba dilakukan dengan maksud agar produk yang yang dikembangkan layak digunakan. Data yang diperoleh kemudian dianalisis dan digunakan untuk memperbaiki atau menyempurnakan produk yang dikembangkan. Dengan proses uji coba produk seperti ini, diharapkan kualitas media yang dikembangkan menjadi lebih baik.

Analisis data dalam penelitian ini berupa analisis kuantitatif dengan mengubah data hasil penilaian ahli media dan ahli materi pada angket kedalam interval skor dengan skala Likert sebagai berikut: 
Tabel 1. Kriteria Penskoran Item pada Agket

\begin{tabular}{lc}
\hline Kriteria & Skor \\
\hline Sangat baik & 5 \\
Baik & 4 \\
Cukup baik & 3 \\
Kurang baik & 2 \\
Sangat kurang baik & 1 \\
\hline
\end{tabular}

Skor dari angket kemudian dijumlahkan. Hasil penjumlahan dikelompokkan ke dalam kriteria penilaian dengan interval sebagaimana disajikan pada Tabel 2 .

Tabel 2. Kriteria Penilaian Aspek Materi dan Aspek Tampilan

\begin{tabular}{lcl}
\hline Interval Skor & & Kriteria \\
\hline $\mathrm{X}>\overline{X_{i}}+1,80 \mathrm{Sb}_{\mathrm{i}}$ & $\mathrm{X}>4,21$ & Sangat Baik \\
$\overline{X_{i}}+0,60 \mathrm{Sb}_{\mathrm{i}}<\mathrm{X} \leq \overline{X_{i}}+3,40<\mathrm{X} \leq 4,21$ & Baik \\
$1,80 \mathrm{Sb}_{\mathrm{i}}$ & \\
$\overline{X_{i}}-0,60 \mathrm{Sb}_{\mathrm{i}}<\mathrm{X} \leq \overline{X_{i}}+2,60<\mathrm{X} \leq 3,40$ & Cukup baik \\
$0,60 \mathrm{Sb}_{\mathrm{i}}$ & & \\
$\overline{X_{i}}-1,80 \mathrm{Sb}_{\mathrm{i}}<\mathrm{X} \leq \overline{X_{i}}-$ & $1,79<\mathrm{X} \leq 2,60$ & Kurang baik \\
$0,60 \mathrm{Sb}_{\mathrm{i}}$ & & \\
$\mathrm{X} \leq \overline{X_{i}}-1,80 \mathrm{Sb}_{\mathrm{i}}$ & $\mathrm{X} \leq 1,79$ & $\begin{array}{l}\text { Sangat } \\
\text { kurang baik }\end{array}$ \\
\hline
\end{tabular}

Tabel 3. Kriteria Penilaian Aspek Daya Tarik

\begin{tabular}{lll}
\hline Interval Skor & & Kriteria \\
\hline $\mathrm{X}>\overline{X_{i}}+1,80 \mathrm{Sb}_{\mathrm{i}}$ & $\mathrm{X}>4,21$ & Sangat menarik \\
$\overline{X_{i}}+0,60 \mathrm{Sb}_{\mathrm{i}}<\mathrm{X} \leq \overline{X_{i}}+3,40<\mathrm{X} \leq 4,21$ & Menarik \\
$1,80 \mathrm{Sb}_{\mathrm{i}}$ & & \\
$\overline{X_{i}}-0,60 \mathrm{Sb}_{\mathrm{i}}<\mathrm{X} \leq \overline{X_{i}}+$ & $2,60<\mathrm{X} \leq 3,40$ & Cukup \\
$0,60 \mathrm{Sb}_{\mathrm{i}}$ & & menarik \\
$\overline{X_{i}}-1,80 \mathrm{Sb}_{\mathrm{i}}<\mathrm{X} \leq \overline{X_{i}}-$ & $1,79<\mathrm{X} \leq 2,60$ & $\begin{array}{l}\text { Kurang } \\
\text { menarik }\end{array}$ \\
$0,60 \mathrm{Sb}_{\mathrm{i}}$ & & Sengat kurang \\
$\mathrm{X} \leq \overline{X_{i}}-1,80 \mathrm{Sb}_{\mathrm{i}}$ & $\mathrm{X} \leq 1,79$ & $\begin{array}{l}\text { Sangarik } \\
\text { menarik }\end{array}$ \\
\hline
\end{tabular}

Keterangan:

Rerata ideal $\left(\overline{X_{i}}\right): 1 / 2 \times$ (skor maksimal + skor minimal)

$\mathrm{Sb}_{\mathrm{i}} \quad: 1 / 6 \times$ (skor maksimal - skor minimal)

Skor maksimal $: 5$

Skor minimal $\quad: 1$

Rerata skor ideal $\left(\overline{X_{i}}\right)=1 / 2 \times(5+1)=3$

Simpangan baku skor ideal $\left(\mathrm{Sb}_{\mathrm{i}}\right)=1 / 6 \times(5-1)=0,67$

(Sukardjo, 2009)

\section{Hasil Penelitian dan Pembahasan}

\section{Hasil Pengembangan Rancangan Produk}

Penelitian dan pengembangan ini difokuskan pada teknis pembuatan produk multimedia pembelajaran tentang kartografi khususnya menghitung volume cekungan. Langkah awal adalah mengumpulkan beberapa konsep dan rumus-rumus yang berkaitan dengan teknis/ metode menghitung volume cekungan pada sebuah peta. Pembuatan media ini tetap memperhatikan silabus yang telas disusun.

Pengembangan produk awal multimedia pembelajaran diawali dengan pengembangan silabus. Adapun langkahlangkah dalam pengembangan silabus meliputi: (1) menentukan standar kompetensi, (2) menentukan kompetensi dasar, (3) melakukan analisis pembelajaran, (4) merumuskan indikator, (5) mengembangkan instrumen penilaian, (6), mengembangkan materi pembelajaran, (7) menyusun strategi pembelajaran.

Silabus digunakan sebagai pedoman dalam proses pembelajaran yang dituangkan ke dalam multimedia yang dikembangkan. Berdasarkan silabus tersebut kemudian dikembangkan multimedia pembelajaran, yaitu (1) membuat flowchart (terlampir); (2) membuat storyboard (terlampir); (3) mengumpulkan bahan-bahan pendukung; (4) memproduksi media pembelajaran menggunakan software power point; (5) tes program untuk memastikan apakah hasilnya seperti yang diinginkan.

Produk multimedia yang dikembangkan berupa CD (Compact Disk) pembelajaran, dimana pengguna dapat berinteraksi, melalui mouse atau keyboard untuk mendapatkan respon dari komputer berupa teks, gambar, animasi, narasi. Adapun hasil identifikasi kerja multimedia yang dikembangkan antara lain sebagai berikut.

Setelah program dijalankan akan tampil halaman intro "selamat datang" pada multimedia pembelajaran, identitas penulis dan selanjutnya akan sampai pada 
slide materi pembelajaran. Dalam slide ini ada tombol pilihan untuk klik sebelumnya atau klik selanjutnya. Tampilan selanjutnya adalah menu utama yang terdiri dari bagian-bagian isi dari multimedia yang dikembangkan yaitu: petunjuk, pendahuluan, materi, latihan dan evaluasi.

Pada slide menu utama ini tersedia pilihan untuk memilih konsep atau pedoman pemahaman yang terkait dengan submateri yang akan lebih dulu dipelajari dalam memahami teknis menghitung volume cekungan. Menu "materi" bila di-klik akan muncul beberapa submateri. Slide submateri tersebut berisi penjelasan mengenai konsep-konsep yang berkaitan dengan teknis menghitung volume cekungan.

Materi telah disusun secara urut sesuai dengan runtutan materi, disamping berupa teks juga ada gambar, dan animasi proses menghitung volume cekungan. Animasi digunakan untuk memperlihatkan teknis menghitung volume cekungan secara runtut. Setiap slide bila masih ada materi lain pada slide berikutnya selalu disediakan tombol "next", tetapi bila pengguna memerlukan melihat kembali pada slide sebelumnya pada slide tersebut disediakan tombol "back". Evaluasi dilakukan dengan cara memberikan latihan soal untuk menghitung volume cekungan dari sebuah peta.

Setelah produk awal seperti digambarkan di atas dapat hasilkan, dilanjutkan pada tahap validasi, yaitu validasi oleh ahli materi dan ahli media. Hasil validasi digunakan sebagai dasar untuk revisi produk tahap pertama. Produk hasil revisi tahap pertama kemudian diuji cobakan dalam kelompok kecil. Hasil uji coba kelompok kecil digunakan sebagai dasar revisi tahap kedua. Produk hasil revisi tahap kedua kemudian diuji cobakan pada kelompok besar. Setelah uji coba tersebut selanjutnya dilakukan revisi akhir.

Deskripsi data hasil validasi oleh ahli materi dan ahli media serta hasil ujicoba pada masing-masing tahap tersebut dipaparkan dalam uraian berikut.

\section{Data Validasi Ahli Materi}

Validasi ahli materi terhadap pengembangan multimedia pembelajaran yang dikembangkan dilakukan oleh seorang Dosen mata kuliah Geomorfologi, Geologi, dan Hidrologi yang sudah cukup kompeten dalam masalah yang terkait dengan volume suatu tubuh air (telaga, rawa, waduk/bendungan, dan danau). Validasi oleh ahli materi dilakukan untuk mendapatkan informasi kesesuaian materi yang digunakan untuk menyusun bahan dalam multimedia yang dikembangkan. Selanjutnya memberi saran masukkan tentang materi yang ada dan materi yang seharusnya dalam pengembangan multimedia pembelajaran yang dikembangkan.

Informasi lebih jelas hasil validasi ahli materi, berupa skor penilaian terhadap aspek instruksonal, aspek materi dan beberapa saran-saran adalah sebagai berikut :

\section{Aspek Instruksional}

Tabel 4. Skor Penilaian Aspek Instruksional Oleh Ahli Materi

\begin{tabular}{|c|c|c|}
\hline Indikator & $\begin{array}{l}\text { Skor Aspek } \\
\text { Instruksional }\end{array}$ & Kriteria \\
\hline $\begin{array}{l}\text { 1. Kesesuaian standar kompetensi } \\
\text { dengan kompetensi dasar. }\end{array}$ & 4 & Baik \\
\hline $\begin{array}{l}\text { 2. Kesesuaian indicator dan } \\
\text { kompetensi dasar }\end{array}$ & 4 & Baik \\
\hline 3. Ketepatan materi dengan silabus & 4 & Baik \\
\hline 4. Kemudahan memahami kalimat & 5 & $\begin{array}{c}\text { Sangat } \\
\text { baik }\end{array}$ \\
\hline 5. Kemudahan memahami materi & 3 & Cukup \\
\hline $\begin{array}{l}\text { 6. Kemampuan memahami petunjuk } \\
\text { belajar }\end{array}$ & 4 & Baik \\
\hline $\begin{array}{l}\text { 7. Kesesuaian latihan dan soal dengan } \\
\text { materi }\end{array}$ & 5 & $\begin{array}{c}\text { Sangat } \\
\text { baik }\end{array}$ \\
\hline 8. Kesesuaian urutan penyajian & 4 & Baik \\
\hline 9. Kesesuaian contoh & 5 & $\begin{array}{c}\text { Sangat } \\
\text { baik }\end{array}$ \\
\hline 10. Kejelasan umpan balik & 5 & $\begin{array}{c}\text { Sangat } \\
\text { baik }\end{array}$ \\
\hline 11. Kemudahan penggunaan program & 5 & $\begin{array}{c}\text { Sangat } \\
\text { baik }\end{array}$ \\
\hline Jumlah & 48 & $\begin{array}{c}\text { Sangat } \\
\text { baik }\end{array}$ \\
\hline
\end{tabular}


Aspek ini dimaksudkan untuk mengetahui kesesuaian dan ketepatan dari ahli materi mengenai berbagai hal yang menyangkut aspek instruksional dalam pembelajaran pada produk multimedia yang telah dikembangkan. Penilaian aspek ini meliputi 11 indikator, hasil penilaian aspek intruksional oleh ahli materi dapat dilihat pada Tabel 4 . Tabel 4 menunjukkan bahwa multimedia yang dikembangkan ini, dilihat dari aspek instruksional oleh ahli materi baik kesesuaian maupun ketepatannya dinyatakan sangat baik.

Hasil penilaian oleh ahli materi menyatakan bahwa multimedia pembelajaran yang dikembangkan, dilihat dari aspek instruksionalnya memiliki rata-rata skor 4,36 dengan kriteria sangat baik.

\section{Aspek Materi}

Tabel 5. Skor Penilaian Aspek Materi Oleh Ahli Materi

\begin{tabular}{llcl}
\hline No & \multicolumn{1}{c}{ Indikator } & $\begin{array}{c}\text { Skor } \\
\text { Aspek } \\
\text { Materi }\end{array}$ & Kriteria \\
\hline 1. & Kejelasan kompetensi dasar & 4 & Baik \\
2. & Kejelasan indikator & 5 & $\begin{array}{l}\text { Sangat } \\
\text { baik }\end{array}$ \\
3. Relevansi materi dengan indikator & 4 & Baik \\
4. & Kejelasan isi materi & 5 & Sangat \\
5. Kelengkapan materi & & baik \\
6. Ketepatan urutan materi & 4 & Baik \\
7. Kedalaman materi & 5 & Sangat \\
8. Kejelasan penyampaian materi & 4 & baik \\
9. Relevansi soal dengan materi & 4 & Baik \\
10. Kecukupan latihan & 4 & Baik \\
11. Relevansi dengan kondisi & 5 & Sangat \\
mahasiswa & & baik \\
12. Relevansi materi dengan & 5 & Sangat \\
mahasiswa & & baik \\
13. Relevansi kalimat dengan & 5 & Sangat \\
mahasiswa & & baik \\
Jumlah & 4 & Baik \\
\hline
\end{tabular}

Penilaian ahli materi mengenai berbagai hal yang menyangkut aspek isi/ materi pada produk multimedia yang telah dikembangkan, hasilnya dapat dilihat pada Tabel 5.

Hasil penilaian oleh ahli materi menyatakan bahwa multimedia pembelajaran yang dikembangkan, dilihat dari aspek materinya memiliki rata-rata skor 4,46 dengan kriteria sangat baik.

\section{Komentar dan Saran Ahli Materi}

Saran ataupun komentar terhadap produk yang dikembangkan dari ahli materi bahwa pengembangan produk multimedia untuk aspek materi dapat diterima dan dapat dilanjutkan karena telah sesuai dan memenuhi unsur kelayakan. Rekomendasi dari ahli materi produk multimedia ini layak untuk di ujicobakan

\section{Data Validasi Ahli Media}

Ahli media yang menjadi validator dalam produk penelitian pengembangan ini adalah seorang ahli media pembelajaran yang telah banyak berkiprah dalam bidang media pembelajaran. Ahli media melakukan penilaian dengan cara memakai produk multimedia tersebut. Satu persatu slide diamati kelengkapannya serta penampilannya. Dengan menggunakan angket yang telah disediakaan ahli media menilai. Jika ada beberapa hal yang masih perlu perbaikan atau revisi, ahli media memberikan saran ataupun komentar terhadap produk yang dikembangkan pada lembar angket yang disediakan, komentar dan saran slide demi slide. Data validasi ahli media diperoleh dengan menggunakan angket berskala Likert.

Disamping menggunakan angket juga dilakukan konsultasi-konsultasi secara langsung. Hasil validasi ahli media digunakan sebagai bahan penyempurnaan multimedia yang dikembangkan.Validasi ahli media tentang pengembangan multimedia pembelajaran kartografi ini, meliputi meliputi aspek yaitu: aspek tampilan, aspek navigasi, aspek pedagogik dan aspek tambahan. Hasilnya secara lengkap sebagai berikut. 


\section{Aspek Tampilan}

Hasil penilaian ahli media tentang multimedia disajikan pada pada Tabel 6 .

Tabel 6. Skor Penilaian Aspek Tampilan oleh Ahli Media

\begin{tabular}{|c|c|c|}
\hline No Indikator & $\begin{array}{c}\text { Skor Aspek } \\
\text { Tampilan }\end{array}$ & Kriteria \\
\hline 1. Ukuran huruf & 5 & Sangat baik \\
\hline 2. Bentuk huruf & 5 & Sangat baik \\
\hline 3. Komposisi kalimat & 4 & Baik \\
\hline 4. Konsistensi kata/istilah & 5 & Sangat baik \\
\hline 5. Sajian animasi & 4 & Baik \\
\hline 6. Komposisi warna & 5 & Sangat baik \\
\hline 7. Daya dukung musik & 4 & Baik \\
\hline 8. Kejelasan suara & 5 & Sangat baik \\
\hline 9. Sajian gambar & 4 & Baik \\
\hline 10. Kualitas gambar & 5 & Sangat baik \\
\hline 11. Tata letak & 5 & Sangat baik \\
\hline 12. Format halaman & 5 & Sangat baik \\
\hline 13. Penomoran & 3 & Cukup \\
\hline 14. Kejelasan uraian materi & 4 & Baik \\
\hline 15. Latihan dan soal & 3 & Cukup \\
\hline Jumlah & 66 & \\
\hline Rata-rata & 4.4 & Sangat baik \\
\hline
\end{tabular}

Aspek tampilan meliputi 15 indikator yang kesemuanya terkait dengan tampilan baik berupa huruf, istilah, kalimat, animasi, warna, tata letak, penomoran, kejelasan uraian termasuk latihan soal yang dibuat.

Hasil penilaian oleh ahli media menyatakan bahwa multimedia pembelajaran yang dikembangkan, dilihat dari aspek tampilannya memiliki rata-rata skor 4,4 dengan kriteria sangat baik.

\section{Aspek Navigasi}

Tabel 7. Skor Penilaian Aspek Navigasi oleh Ahli Media

\begin{tabular}{|c|c|c|}
\hline No Indikator & $\begin{array}{c}\text { Skor } \\
\text { Aspek } \\
\text { Navigasi }\end{array}$ & Kriteria \\
\hline 1. Kejelasan penggunaan program & 4 & Baik \\
\hline 2. Konsistensi navigasi & 5 & Sangat baik \\
\hline 3. Efektivitas navigasi & 5 & Sangat baik \\
\hline 4. Fungsi navigasi & 3 & Cukup \\
\hline 5. Kemudahan pengoperasian & 4 & Baik \\
\hline 6. Konsistensi Button & 5 & Sangat baik \\
\hline 7. Petunjuk keluar & 4 & Baik \\
\hline Jumlah & 30 & \\
\hline Rata-rata & 4.29 & Sangat baik \\
\hline
\end{tabular}

Aspek navigasi meliputi tujuh indikator yang kesemuanya terkait dengan kelengkapan perangkat untuk menjalankan multimedia yang dibuat. Hasil yang diperoleh selengkapnya disajikan pada Tabel 7 .

Hasil penilaian oleh ahli media menyatakan bahwa multimedia pembelajaran yang dikembangkan, dilihat dari aspek navigasi memiliki rata-rata skor 4,29 dengan kriteria sangat baik.

Aspek Pedagogik

Aspek pedagogik meliputi tujuh indikator yang kesemuanya terkait dengan proses pembelajaran diataranya kemudahan memahami materi, membantu memfokuskan perhatian, memudahkan dosen atau mahasiswa. Hasil yang diperoleh selengkapnya dapat dilihat pada Tabel 8.

Tabel 8. Skor Penilaian Aspek Pedagogik oleh Ahli Media

\begin{tabular}{|c|c|c|}
\hline No Indikator & $\begin{array}{c}\text { Skor Aspek } \\
\text { Pedagogik }\end{array}$ & Kriteria \\
\hline 1. Membantu dosen/mahasiswa & 4 & Baik \\
\hline 2. Mempermudah PBM & 5 & $\begin{array}{l}\text { Sangat } \\
\text { baik }\end{array}$ \\
\hline 3. Memberi fokus perhatian & 4 & Baik \\
\hline $\begin{array}{l}\text { 4. Menyesuaikan kemampuan } \\
\text { mahasiswa }\end{array}$ & 5 & $\begin{array}{l}\text { Sangat } \\
\text { baik }\end{array}$ \\
\hline $\begin{array}{l}\text { 5. Latihan soal membantu } \\
\text { mengingat mahasiswa }\end{array}$ & 4 & Baik \\
\hline Jumlah & 22 & \\
\hline Rata-rata & 4.4 & $\begin{array}{l}\text { Sangat } \\
\text { baik }\end{array}$ \\
\hline
\end{tabular}

Hasil penilaian oleh ahli media menyatakan bahwa multimedia pembelajaran yang dikembangkan, dilihat dari aspek navigasi memiliki rata-rata skor 4,4 dengan kriteria sangat baik.

\section{Aspek Tambahan}

Aspek tambahan meliputi empat indikator yang kesemuanya terkait dengan kelengkapan perangkat meliputi petunjuk, ketepatan serta ketepatan multimedia yang dibuat. Hasil yang diperoleh selengkapnya dapat dilihat pada Tabel 9. 
Tabel 9. Skor Penilaian Aspek Tambahan oleh Ahli Media

\begin{tabular}{lcl}
\hline No Indikator & Skor Kriteria \\
\hline 1. Petunjuk penggunaan program & 4 & Baik \\
2. Petunjuk latihan soal & 4 & Baik \\
3. Ketepatan penggunaan waktu & 4 & Baik \\
4. Kualitas produk multimedia & 5 & Sangat baik \\
Jumlah & 17 & \\
Rata-rata & 4.25 & Sangat baik \\
\hline
\end{tabular}

Komentar dan saran ahli media

Berdasarkan penilaian dari ahli media, maka produk multimedia ini layak untuk diujicobakan

\section{Data Uji Coba Lapangan}

Pelaksanaan uji coba kelompok besar/lapangan merupakan uji coba untuk mengukur baik-tidaknya produk multimedia pembelajaran kartografi yang telah dikembangkan, khususnya mengenai menghitung volume cekungan. Dengan uji coba ini, diharapkan akan diketahui hasil evaluasi mahasiswa terhadap pembelajaran kartografi dengan menggunakan multimedia yang telah dikembangkan.

\section{Hasil Uji Coba}

Uji coba lapangan dilakukan pada 25 mahasiswa yang dipilih secara acak, sehingga mahasiswa yang dipilih adalah mahasiswa dengan kemampuan yang heterogen. Pada akhir uji coba ini dilakukan evaluasi dengan diberikan latihan soal untuk menghitung volume cekungan dari suatu peta. Dalam melakukan uji coba pengembang dibantu oleh staf administrasi bagian laboran dan seorang mahasiswa Jurusan Pendidikan Geografi. Informasi secara lebih jelas mengenai skor hasil uji coba lapangan dapat dilihat pada Tabel 10.

Tabel 10.Skor Hasil Uji Coba Lapangan Aspek Daya Tarik

\begin{tabular}{|c|c|c|c|c|c|c|c|c|c|c|c|c|c|}
\hline \multirow{2}{*}{$\begin{array}{l}\text { No } \\
\text { Mhs }\end{array}$} & \multicolumn{10}{|c|}{ No Item } & \multirow[t]{2}{*}{ Jumlah } & \multirow{2}{*}{$\begin{array}{l}\text { Rata } \\
\text {-rata }\end{array}$} & \multirow[t]{2}{*}{ Kriteria } \\
\hline & 1 & 2 & 3 & 4 & 5 & 6 & 7 & 8 & 9 & 10 & & & \\
\hline 1 & 4 & 4 & 5 & 4 & 5 & 4 & 5 & 4 & 4 & 5 & 44 & 4,4 & sangat menarik \\
\hline 2 & 4 & 4 & 4 & 4 & 4 & 3 & 4 & 4 & 3 & 2 & 36 & 3,6 & menarik \\
\hline 3 & 4 & 5 & 4 & 4 & 3 & 4 & 5 & 5 & 5 & 3 & 42 & 4,2 & menarik \\
\hline 4 & 4 & 4 & 3 & 4 & 4 & 4 & 3 & 3 & 3 & 3 & 35 & 3,5 & menarik \\
\hline 5 & 5 & 4 & 4 & 5 & 5 & 4 & 5 & 4 & 4 & 5 & 45 & 4,5 & sangat menarik \\
\hline 6 & 4 & 3 & 4 & 4 & 3 & 3 & 4 & 4 & 4 & 3 & 36 & 3,6 & menarik \\
\hline 7 & 4 & 5 & 4 & 5 & 5 & 4 & 3 & 2 & 3 & 4 & 39 & 3,9 & menarik \\
\hline 8 & 4 & 4 & 4 & 4 & 4 & 5 & 5 & 5 & 5 & 5 & 45 & 4,5 & sangat menarik \\
\hline 9 & 4 & 4 & 5 & 4 & 5 & 4 & 5 & 5 & 5 & 5 & 46 & 4,6 & sangat menarik \\
\hline 10 & 5 & 5 & 4 & 5 & 4 & 4 & 4 & 5 & 5 & 5 & 46 & 4,6 & sangat menarik \\
\hline 11 & 4 & 3 & 4 & 3 & 3 & 2 & 5 & 5 & 4 & 4 & 37 & 3,7 & menarik \\
\hline 12 & 4 & 5 & 5 & 5 & 4 & 4 & 5 & 5 & 4 & 4 & 45 & 4,5 & sangat menarik \\
\hline 13 & 5 & 4 & 5 & 4 & 4 & 4 & 5 & 4 & 4 & 4 & 43 & 4,3 & sangat menarik \\
\hline 14 & 5 & 5 & 4 & 4 & 4 & 3 & 4 & 5 & 3 & 4 & 41 & 4,1 & menarik \\
\hline 15 & 5 & 5 & 5 & 5 & 5 & 5 & 4 & 4 & 3 & 3 & 44 & 4,4 & sangat menarik \\
\hline 16 & 4 & 4 & 4 & 4 & 4 & 4 & 4 & 4 & 4 & 3 & 39 & 3,9 & menarik \\
\hline 17 & 4 & 5 & 5 & 4 & 4 & 5 & 4 & 4 & 4 & 4 & 43 & 4,3 & sangat menarik \\
\hline 18 & 5 & 5 & 4 & 5 & 5 & 4 & 5 & 5 & 3 & 4 & 45 & 4,5 & sangat menarik \\
\hline 19 & 4 & 5 & 5 & 5 & 4 & 4 & 5 & 5 & 4 & 4 & 45 & 4,5 & sangat menarik \\
\hline 20 & 4 & 5 & 5 & 5 & 4 & 4 & 4 & 5 & 4 & 3 & 43 & 4,3 & sangat menarik \\
\hline 21 & 5 & 5 & 4 & 5 & 4 & 4 & 4 & 4 & 4 & 3 & 42 & 4,2 & menarik \\
\hline 22 & 5 & 4 & 4 & 4 & 5 & 5 & 5 & 5 & 4 & 5 & 46 & 4,6 & sangat menarik \\
\hline 23 & 5 & 4 & 4 & 4 & 3 & 3 & 4 & 4 & 4 & 3 & 38 & 3,8 & menarik \\
\hline 24 & 4 & 5 & 5 & 4 & 4 & 3 & 5 & 5 & 4 & 4 & 43 & 4,3 & sangat menarik \\
\hline 25 & 5 & 5 & 4 & 5 & 4 & 4 & 4 & 5 & 5 & 5 & 46 & 4,6 & sangat menarik \\
\hline Jumlah & 110 & 111 & 108 & 109 & 103 & 97 & 110 & 110 & 99 & 97 & 1054 & 4,22 & \\
\hline Rerata & 4,4 & 4,44 & 4,32 & 4,36 & 4,12 & 3,88 & 4,4 & 4,4 & 3,96 & 3,88 & & & \\
\hline Kriteria & $\mathrm{SM}$ & $\mathrm{SM}$ & $\mathrm{SM}$ & $\mathrm{SM}$ & $\mathrm{SM}$ & M & $\mathrm{SM}$ & $\mathrm{SM}$ & M & $\mathrm{M}$ & & & \\
\hline
\end{tabular}


Berdasarkan hasil uji coba lapangan aspek daya tarik untuk indikator nomor 1 , $2,3,4,5,7$, dan 8 yaitu media pembelajaran mudah digunakan, materi yang disajikan mudah dipahami, memberikan semangat dalam belajar, kejelasan contoh-contoh yang diberikan, memberikan kesempatan belajar sesuai dengan kecepatan siswa, kemenarikan gambar yang disajikan, dan kemenarikan animasi memperoleh penilaian dengan kriteria sangat menarik. Sedangkan untuk indikator nomor 6, 9, dan 10 yaitu soal yang bervariasi menghindari kebosanan, pemilihan komposisi warna, dan daya dukung musik memperoleh penilaian menarik.

\section{Data Hasil Belajar}

Tabel 11. Hasil Belajar Mahasiswa

\begin{tabular}{|c|c|c|}
\hline $\begin{array}{c}\text { Nomor } \\
\text { Mahasiswa }\end{array}$ & Nilai & $\begin{array}{l}\text { Tuntas/ } \\
\text { Tidak tuntas }\end{array}$ \\
\hline 1 & 100 & Tuntas \\
\hline 2 & 100 & Tuntas \\
\hline 3 & 100 & Tuntas \\
\hline 4 & 95 & Tuntas \\
\hline 5 & 80 & Tuntas \\
\hline 6 & 100 & Tuntas \\
\hline 7 & 100 & Tuntas \\
\hline 8 & 100 & Tuntas \\
\hline 9 & 100 & Tuntas \\
\hline 10 & 100 & Tuntas \\
\hline 11 & 100 & Tuntas \\
\hline 12 & 100 & Tuntas \\
\hline 13 & 100 & Tuntas \\
\hline 14 & 100 & Tuntas \\
\hline 15 & 100 & Tuntas \\
\hline 16 & 100 & Tuntas \\
\hline 17 & 95 & Tuntas \\
\hline 18 & 95 & Tuntas \\
\hline 19 & 85 & Tuntas \\
\hline 20 & 100 & Tuntas \\
\hline 21 & 100 & Tuntas \\
\hline 22 & 100 & Tuntas \\
\hline 23 & 100 & Tuntas \\
\hline 24 & 100 & Tuntas \\
\hline 25 & 100 & Tuntas \\
\hline Jumlah & 2450 & \multirow{2}{*}{ Tuntas } \\
\hline Rata-rata & 98 & \\
\hline
\end{tabular}

Tujuan dari pengembangan multimedia pembelajaran adalah untuk mening- katkan mutu pembelajaran dan diharapkan dapat meningkatkan hasil belajar. Untuk mengetahui apakah multimedia pembelajaran yang dikembangkan mampu mengoptimalkan hasil belajar mahasiswa, di akhir uji coba dilakukan evaluasi dengan latihan soal untuk mengukur pemahaman mahasiswa.

Berdasarkan uji coba lapangan, diketahui bahwa multimedia pembelajaran yang dikembangkan mampu mengoptimalkan hasil belajar mahasiswa. Seluruh mahasiswa tuntas dalam mengerjakan soal latihan yang diberikan. Penjabaran hasil evaluasi disajikan pada Tabel 11.

Analisis Data Validasi Ahli Materi dan Ahli Media

Data yang diperoleh dari hasil validasi ahli materi dan ahli media, dipergunakan untuk mengadakan revisi/perbaikan terhadap multimedia pembelajaran yang dikembangkan baik dari aspek materi dan aspek tampilan, sesuai dengan saransaran ahli materi dan ahli media.

\section{Penilaian Ahli Materi}

Penilaian yang dilakukan oleh ahli materi terdiri dari dua aspek yaitu aspek instruksional dan aspek materi.

Tabel 12. Distribusi Frekuensi Skor Hasil Validasi Ahli Materi Aspek Instruksional

\begin{tabular}{lcc}
\hline \multicolumn{1}{c}{ Kriteria } & Frekuensi & $\%$ \\
\hline Sangat baik & 5 & 45,45 \\
Baik & 5 & 45,45 \\
Cukup & 1 & 9,09 \\
Kurang & 0 & 0,00 \\
Sangat kurang & 0 & 0,00 \\
\hline
\end{tabular}

Aspek instruksional ada 11 indikator, penilaian oleh ahli materi menunjukkan 45,45\% memberi kriteria sangat baik, dan 45,45\% memberi kriteria baik. Sedangkan sisanya 9,09\% adalah kriteria cukup. Pada penilaian aspek instruksional oleh ahli media tidak ada saran untuk mengubah atau merevisi. Dengan demi- 
kian multimedia yang dikembangkan dalam aspek instruksional termasuk dalam kategori "baik".

Skor yang diberikan oleh ahli materi untuk aspek instruksional dapat dilihat pada Gambar 1.

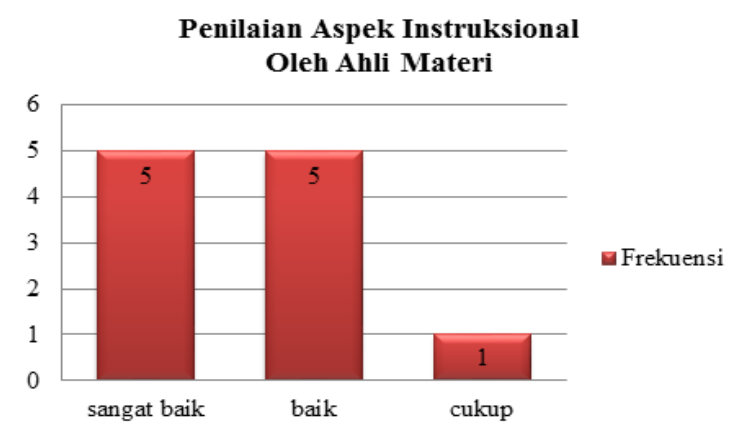

Gambar 1. Hasil Penilaian Aspek Instruksional

Penilaian untuk aspek materi terdiri dari 13 indikator yang hasilnya disajikan pada Tabel 13.

Tabel 13. Distribusi Frekuensi Skor Hasil Validasi Ahli Materi Aspek Materi

\begin{tabular}{lcc}
\hline \multicolumn{1}{c}{ Kriteria } & Frekuensi & $\%$ \\
\hline Sangat baik & 6 & 46,15 \\
Baik & 7 & 53,85 \\
Cukup & 0 & 0,00 \\
Kurang baik & 0 & 0,00 \\
Sangat kurang baik & 0 & 0,00 \\
\hline
\end{tabular}

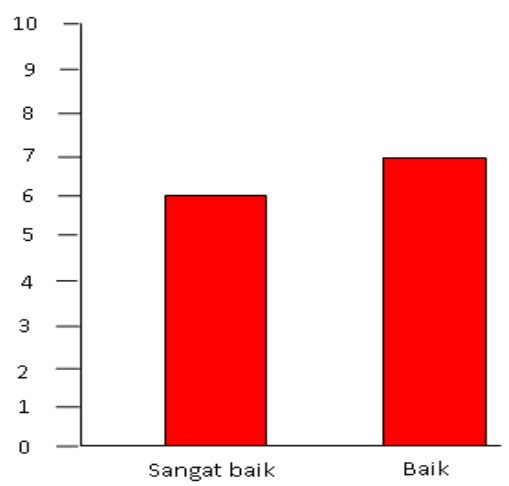

Gambar 2. Hasil Penilaian Aspek Materi Oleh Ahli Materi

Aspek materi ada 13 indikator, penilaian oleh ahli materi menunjukkan $46,15 \%$ indikator dinilai dengan kriteria sangat baik, dan 53,85\% indikator dinilai dengan kriteria baik. Pada penilaian aspek materi oleh ahli media tidak ada saran untuk mengubah atau merevisi. Dengan demikian multimedia yang dikembangkan baik dalam aspek baik. Skor yang diberikan oleh ahli materi untuk aspek materi dapat dilihat pada Gambar 2.

\section{Penilaian Ahli Media}

Penilaian yang dilakukan oleh ahli media terdiri dari empat aspek yaitu aspek tampilan, aspek navigasi, aspek pedagogik dan aspek tambahan.

Tabel 14. Distribusi Frekuensi Skor Hasil Validasi Ahli Media Aspek Tampilan

\begin{tabular}{lcc}
\hline \multicolumn{1}{c}{ Kriteria } & Frekuensi & $\%$ \\
\hline Sangat menarik & 8 & 53,33 \\
Baik & 5 & 33,33 \\
Cukup menarik & 2 & 13,33 \\
Kurang menarik & 0 & 0,00 \\
Sangat kurang menarik & 0 & 0,00 \\
\hline
\end{tabular}

Aspek tampilan ada 15 indikator, penilaian oleh ahli materi menunjukkan $53,33 \%$ indikator dinilai dengan kriteria sangat baik, dan 33,33\% indikator dinilai dengan kriteria baik. Ada 13,33\% indikator dari aspek tampilan yang diberi nilai kriteria cukup menarik. Pada penilaian aspek tampilan oleh ahli media tidak ada saran untuk mengubah atau merevisi. Dengan demikian multimedia yang dikembangkan dalam aspek tampilan termasuk dalam kategori "baik". Skor yang diberikan oleh ahli media untuk aspek tampilan dapat dilihat pada Gambar 3.

\section{Penilaian Aspek Tampilan Oleh Ahli Media}

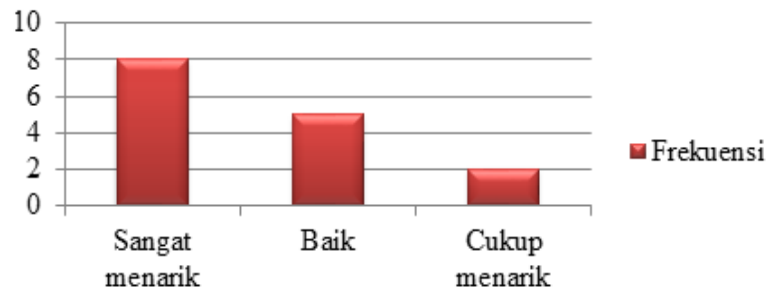

Gambar 3. Hasil Penilaian Aspek Tampilan oleh Ahli Media 
Penilaian untuk aspek navigasi terdiri dari tujuh indikator, hasilnya seperti Tabel 15.

Tabel 15. Distribusi Frekuensi Skor Hasil Validasi Ahli Media Aspek Navigasi

\begin{tabular}{lcc}
\hline \multicolumn{1}{c}{ Kriteria } & Frekuensi & $\%$ \\
\hline Sangat baik & 3 & 42,86 \\
Baik & 3 & 42,86 \\
Cukup & 1 & 14,28 \\
Kurang baik & 0 & 0,00 \\
Sangat kurang baik & 0 & 0,00 \\
\hline
\end{tabular}

Aspek navigasi ada 7 indikator. Penilaian oleh ahli materi menunjukkan $42,86 \%$ indikator dinilai dengan kriteria sangat baik, dan $42,86 \%$ indikator dinilai dengan kriteria baik. Ada 14,28\% indikator dari aspek tampilan yang diberi nilai kriteria cukup. Skor yang diberikan oleh ahli media untuk aspek navigasi dapat dilihat pada Gambar 4.

\section{Penilaian Aspek Navigasi Oleh Ahli Media}

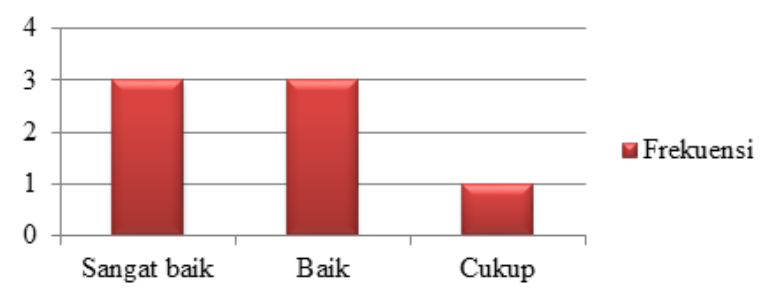

Gambar 4. Hasil Penilaian Aspek Navigasi Oleh Ahli Media

Dengan demikian multimedia yang dikembangkan dalam aspek navigasi termasuk dalam kategori "baik".

\begin{tabular}{lcc}
$\begin{array}{l}\text { Tabel 16. Distribusi Frekuensi Skor Hasil } \\
\text { Validasi Ahli Media Aspek } \\
\text { Pedagogik }\end{array}$ \\
\multicolumn{1}{c}{ Kriteria } & Frekuensi & $\%$ \\
\hline Sangat baik & 3 & 42,86 \\
Baik & 3 & 42,86 \\
Cukup & 1 & 14,28 \\
Kurang baik & 0 & 0,00 \\
Sangat kurang baik & 0 & 0,00 \\
\hline
\end{tabular}

Aspek pedagogik ada 5 indikator. Penilaian oleh ahli materi menunjukkan
$40 \%$ indikator dinilai dengan kriteria sangat baik, dan 60\% indikator dinilai dengan kriteria baik. Skor yang diberikan oleh ahli media untuk aspek pedagogik dapat dilihat pada Gambar 5.

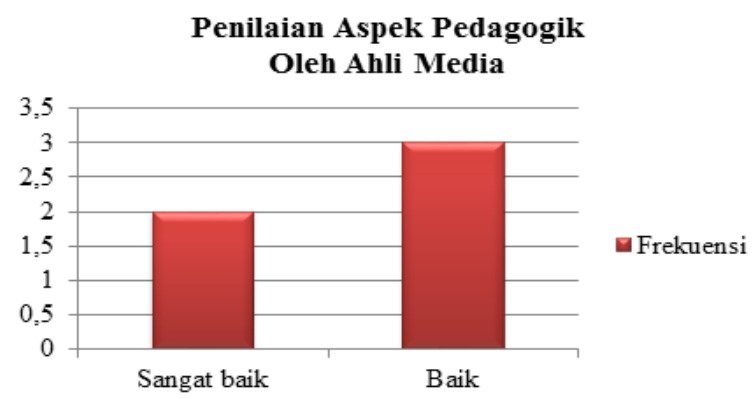

Gambar 5. Hasil Penilaian Aspek Pedagogik Oleh Ahli Media

Pada penilaian aspek pedagogik oleh ahli media tidak ada saran untuk mengubah atau merevisi. Dengan demikian multimedia yang dikembangkan dalam aspek pedagogik termasuk dalam kategori "baik". Penilaian untuk aspek tambahan terdiri dari tujuh indikator, hasilnya seperti Tabel 17.

Tabel 17. Distribusi Frekuensi Skor Hasil Validasi Ahli Media Aspek Tambahan

\begin{tabular}{lcc}
\hline \multicolumn{1}{c}{ Kriteria } & Frekuensi & $\%$ \\
\hline Sangat baik & 2 & 40 \\
Baik & 3 & 60 \\
Cukup baik & 0 & 0,00 \\
Kurang baik & 0 & 0,00 \\
Sangat kurang baik & 0 & 0,00 \\
\hline
\end{tabular}

Penilaian Aspek Tambahan Oleh Ahli Media

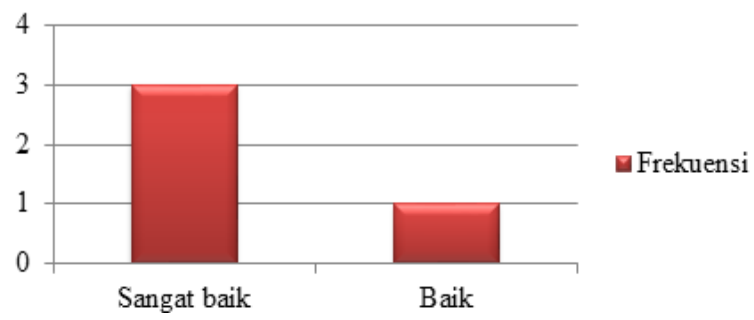

Gambar 6. Hasil Penilaian Aspek Tambahan Oleh Ahli Media

Aspek tambahan ada 4 indikator. Penilaian oleh ahli materi menunjukkan 
$25 \%$ indikator dinilai dengan kriteria sangat baik, dan 75\% indikator dinilai dengan kriteria baik. Pada penilaian aspek tambahan oleh ahli media tidak ada saran untuk mengubah atau merevisi. Dengan demikian multimedia yang dikembangkan dalam aspek tambahan termasuk dalam kategori "baik". Skor yang diberikan oleh ahli media pada aspek tambahan dapat dilihat pada Gambar 5.

\section{Analisis Data Uji Coba Lapangan}

Berdasarkan skor hasil uji coba lapangan kemudian dilakukan analisis untuk mengetahui kualitas multimedia yang dikembangkan. Skor yang diberikan oleh mahasiswa untuk aspek daya tarik pada uji coba lapangan dapat dilihat pada Tabel 18 dan Gambar 7.

Tabel 18. Distribusi Frekuensi Skor Hasil Uji Coba Aspek Daya tarik

\begin{tabular}{lcc}
\hline Kriteria & Frekuensi & $\%$ \\
\hline Sangat baik & 1 & 25 \\
Baik & 3 & 75 \\
Cukup & 0 & 0,00 \\
Kurang baik & 0 & 0,00 \\
Sangat kurang baik & 0 & 0,00 \\
\hline
\end{tabular}

Untuk lebih jelasnya, perbandingan distribusi frekuensi skor hasil uji coba aspek daya tarik dapat dilihat pada grafik Gambar 6.

Distribusi Frekuensi Skor Hasil Uji Coba Lapangan Aspek Daya Tarik

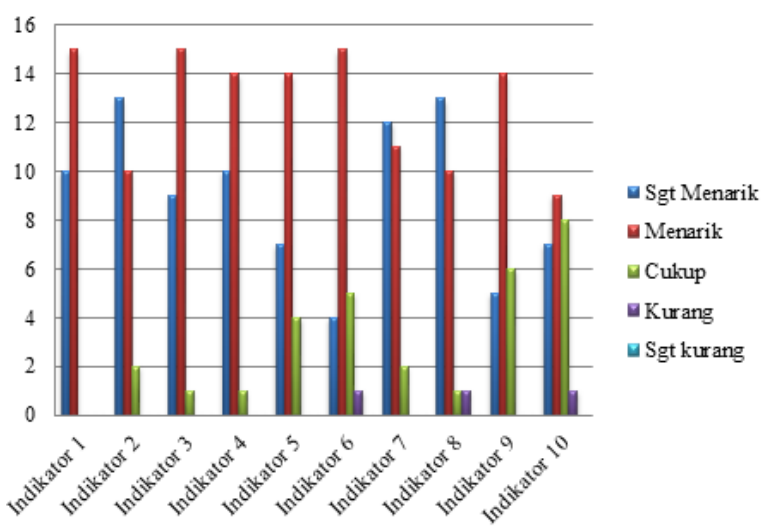

Gambar 7. Hasil Penilaian Aspek Daya Tarik Pada Uji Coba Lapangan
Dari aspek daya tarik pada uji coba lapangan menunjukkan sebagian besar indikator didominasi dengan penilaian sangat menarik dengan rata-rata skor 4,22. Hal itu menujukkan bahwa multimedia pembelajaran tersebut sangat menarik ketika digunakan dalam proses pembelajaran.

Dengan melakukan analisis dapat diketahui kekurangan dan kelebihan multimedia pembelajaran yang dapat dijadikan dasar untuk melakukan tindak lanjut berupa revisi.

\section{Analisis Data Hasil Belajar}

Untuk mengetahui efektifitas produk multimedia pembelajaran yang dikembangkan, maka pada uji coba lapangan perlu dilakukan pengukuran hasil belajar. Berdasarkan tabel hasil belajar mahasiswa (Tabel 11) dapat diketahui bahwa multimedia pembelajaran yang dikembangkan efektif dan dapat digunakan dalam pembelajaran karena $\mathbf{1 0 0 \%}$ mahasiswa dapat tuntas dalam mencapai kompetensi. Dari kegiatan uji coba yang telah dilaksanakan tampak sekali bahwa mahasiswa sangat antusias belajar dengan menggunakan multimedia yang telah dikembangkan. Dengan demikian maka produk multimedia pembelajaran layak untuk digunakan.

\section{Kajian Produk Akhir}

Pengembangan multimedia pembelajaran telah dilakukan melalui beberapa tahapan yaitu studi kepustakaan, desain pembelajaran, produksi multimedia pembelajaran, validasi, uji coba, dan revisi. Berdasarkan validasi oleh ahli materi, ahli media, uji coba lapangan dan hasil analisis data dapat diketahui kualitas media pembelajaran yang dikembangkan termasuk baik dan sangat baik.

Aspek multimedia yang direvisi berdasarkan data yang diperoleh selama uji coba serta masukan dari ahli materi, ahli media, dan mahasiswa selaku pengguna. Adapun kualitas multimedia pembelajaran ini dapat diketahui dari beberapa aspek berikut. 
Kualitas aspek instruksional dengan rata-rata skor 4.36 termasuk kriteria sangat baik. Kualitas aspek materi dengan dengan rata- rata skor 4.46, termasuk kriteria sangat baik. Kualitas aspek tampilan dengan rata-rata skor 4.4 termasuk kriteria sangat baik. Kualitas aspek navigasi ratarata skor 4.28 termasuk kriteria sangat baik. Kualitas aspek pedagogik dengan rata-rata skor 4.4 termasuk kriteria sangat baik. Kualitas aspek tambahan rata-rata skor 4.25 termasuk kriteria sangat baik. Pada uji coba lapangan, tanggapan mahasiswa tentang daya tarik media termasuk kriteria sangat menarik dengan skor 4.216. Dari hasil evaluasi (hasil belajar) dapat dikatakan bahwa media pembelajaran yang dikembangkan sangat efektif dan dapat digunakan dalam pembelajaran karena 100 $\%$ mahasiswa dapat mencapai kompetensi.

\section{Simpulan dan Saran}

\section{Simpulan}

Berdasarkan hasil penelitian pengembangan multimedia pembelajaran kartografi khususnya mengenai teknis menghitung volume cekungan, dapat disimpulkan hal-hal sebagai berikut.

Tahapan proses pengembangan multimedia pembelajaran kartografi khususnya mengenai teknis menghitung volume cekungan, meliputi: Studi pendahuluan, penyusunan desain pembelajaran, produksi multimedia, uji coba produk, dan revisi produk.

Kelayakan dan kualitas multimedia pembelajaran kartografi yang dikembangkan, adalah sebagai berikut. Kualitas aspek instruksional dengan rata-rata skor 4.36 termasuk kriteria sangat baik. Kualitas aspek materi dengan dengan rata- rata skor 4.46, termasuk kriteria sangat baik. Kualitas aspek tampilan dengan rata-rata skor 4.4 termasuk kriteria sangat baik. Kualitas aspek navigasi rata-rata skor 4.28 termasuk kriteria sangat baik. Kualitas aspek pedagogik dengan rata-rata skor 4.4 termasuk kriteria sangat baik. Kualitas aspek tam- bahan rata-rata skor 4.25 termasuk kriteria sangat baik. Pada uji coba lapangan, tanggapan mahasiswa tentang daya tarik media termasuk kriteria sangat menarik dengan skor 4.216. dari hasil evaluasi (hasil belajar) dapat dikatakan bahwa media pembelajaran yang dikembangkan sangat efektif dan dapat digunakan dalam pembelajaran karena $100 \%$ mahasiswa dapat mencapai kompetensi.

\section{Saran}

Berdasarkan kesimpulan tersebut, maka dapat disampaikan saran-saran sebagai berikut: Pengembangan multimedia pembelajaran menggunakan program power point sebaiknya dilakukan secara optimal agar dapat menghasilkan bahan ajar yang efektif untuk mencapai kompetensi pembelajaran. Pengembangan multimedia yang lengkap sangatlah rumit dan kompleks, dalam penelitian pengembangan ini hanya merupakan bagian yang sangat kecil dari materi kartografi. Sebaiknya dalam pemanfaatan multimedia, juga ditambahkan materi-materi relevan yang belum tercantum baik secara lisan/penugasan kepada mahasiswa untuk mencari bacaan-bacaan yang terkait sehingga dapat memperkaya pengetahuan mahasiswa. Multimedia pembelajaran yang dikembangkan, jika dimanfaatkan dengan baik akan dapat meningkatkan hasil belajar. Oleh karena itu meskipun multimedia ini masih sangat sederhana, namun sudah dapat dimanfaatkan untuk mencapai kompetensi pembelajaran yang diharapkan khususnya mengenai teknis menghitung volume cekungan. Multimedia pembelajaran kartografi ini dapat dikembangkan lebih lanjut dengan cara menambah penjelasan, gambar, animasi yang terkait dengan materi, agar nantinya multimedia yang dikembangkan menjadi lebih sempurna. Karena evaluasi yang dilakukan oleh pengembang masih terbatas pada evaluasi formatif yang mencakup aspek materi, aspek tampilan, dan aspek daya tarik, maka peneliti dan pengembang selanjutnya akan lebih baik, bila evaluasi di- 
lakukan pada ahli yang lebih spesifik, sasaran uji coba yang lebih luas sehingga akan menghasilkan multimedia yang lebih lengkap akurat dan sesuai dengan kenyataan di lapangan.

\section{Daftar Pustaka}

Arsyad, A. (2005). Media pembelajaran. Jakarta: Raja Grafindo Persada.

Borg, W. R., \& Gall, M. D. (1983). Educational research: An introduction (4th ed.). New York: Longman Publishing.

Dick, W., Carey, L., \& Carey, J. O. (2005). The systematic design of instruction (6th ed.). Boston: Pearson/Allyn and Bacon.

Gagne, R. M., Briggs, L. J., \& Wager, W. W. (1992). Principle of instructional design (4th ed.). Fort Worth, TX: Harcourt Brace Jovanovich.

Sadiman, A. S., Raharjo, R., \& Haryono, A. (2009). Media pendidikan: pengertian, pengembangan dan pemanfaatannya. Jakarta: PT. Raja Grafindo Persada.

Sandy, I. M. (1986). Esensi kartografi. Jakarta: Jurusan Geografi FMIPA UI.

Sukardjo. (2009). Evaluasi pembelajaran/perkuliahan bidang studi. Yogyakarta: Program Pascasarjana Universitas Negeri Yogyakarta.

Whitworth, S. A., \& Berson, M. J. (2003). Computer technology in the social studies: An examination of the effectiveness literature (1996-2001). Contemporary Issues in Technology and Teacher Education, 2(4). Retrieved from http://www.citejournal.org/volum e-2/issue-4-02/socialstudies/computer-technology-inthe-social-studies-an-examinationof-the-effectiveness-literature-19962001 